\title{
The Effects of Metabolic Syndrome on Aortic Distensibility in Patients with Angiographically Normal Coronary Arteries
}

\author{
Koroner Arterler Normal Olan Hastalarda \\ Metabolik Sendromun Aortik Distensibilite Üzerine Etkisi
}

Ali Emül', Kemal Karaağaç ${ }^{4}$, Zeynel Abidin Yetgin ${ }^{3}$, Hakan Uçar ${ }^{5}$, İbrahim Baran², Ali Aydınlar²

${ }^{1}$ Kars State Of Hospital, Department Of Cardiology

2 Uludag medical faculty, Department of Cardiology

${ }^{3}$ Bolvadin State of hospital, Department of Cardiology

${ }^{4}$ Bursa Postgraduate Hospital, Department Of Cardiology

${ }^{5}$ Bursa State of hospital, Department of Cardiology

\section{Abstract}

Objective: In this study we aimed to investigate the parameters of aortic stiffness that were measured angiographically and the factors that effect these parameters in patients diagnosed as having metabolic syndrome and whose coronary arteries were normal angiographically.

Materials and Methods: Thirty patients with metabolic syndrome and twenty patients without metabolic syndrome were included. Hemodynamic measurements were made during cardiac catheterization while the patients were in supine position. The systolic and diastolic diameters of aorta and parameters associated with aortic stiffness aortic strain and distensibility were measured.

Results: When compared with the control group the systolic and diastolic blood pressure, pulse pressure, waist circumference, triglyceride and fasting plasma glucose levels were higher and HDL cholesterol level was lower in the metabolic syndrome group. Aortic strain was higher in the metabolic syndrome group but the statistical relation was non-significant $(p=0,181)$. Moreover the distensibility was lower in the metabolic syndrome group and the statistical relation was significant $(p$

Conclusion: Patients with metabolic syndrome should be evaluated for aortic stiffness. Thus Thus morbidity and mortality of these patients can be prevented by treatment of risk factors.
Özet

Amaç: Bu çalışmada, metabolik sendrom tanısı alan ve anjiyografik olarak koroner arterleri normal saptanan hastalarda metabolik sendromun invazif olarak ölçülmüş aort sertlik parametrelerine olan etkilerini ortaya koymayı amaçladık.

Gereç ve Yöntemler: Çalışmaya metabolik sendrom tanısı konan 30 hasta ve kontrol grubu olarak metabolik sendrom tanısı bulunmayan 20 hasta alındı. Hemodinamik ölçümler hasta yatar pozisyonda kardiyak kateterizasyon yapımı esnasında değerlendirildi. Aort sistolik ve diyastolik çapları ölçüldü ve aort sertliğinin göstergeleri olan aort gerilimi ve esneyebilirliği hesaplandı. Bulgular: Metabolik sendrom grubunda, kontrol grubu ile karşılaştırıldığında beklendiği üzere sistolik ve diyastolik kan basıncı, nabız basıncı, bel çevresi, trigliserid düzeyi, açlık kan şekeri değerleri daha yüksek, HDL-kolesterol düzeyleri düşük bulundu. Metabolik sendrom grubunda aort gerilimi istatistiksel olarak anlamlı olmamakla birlikte daha yüksek saptandı( $p=0.181)$. Aort esneyebiliriği ise istatistiksel olarak anlamlı olarak daha düşük idi(p Sonuç: Metabolik sendromlu hastalarda arteryel sertlik parametreleri değerlendirilir. Risk faktörlerine yönelik tedavi yapılarak kardiyovasküler hastalıklar ve mortalitede azalma sağlanabilir.

Anahtar Kelimeler: Metabolik sendrom, aortik fonksiyon, arteryel sertlik

Başvuru Tarihi: 05.12.2012 Kabul Tarihi: 04.03.2013 


\section{Introduction:}

Metabolic syndrome (MetS) is defined as the clustering of cardiovascular risk factors such as increased blood pressure, insulin resistance, dyslipidemia, central obesity, high triglyceride and low high-density lipoprotein cholesterol concentrations. ${ }^{1}$ Presence of MetS is associated with increased risk for cardiovascular morbidity and mortality ${ }^{2}$ as well as development of type 2 diabetes mellitus (T2DM). ${ }^{3}$ Two recently published studies have shown that in the in patients with the MetS is associated with increased carotid intima-media thickness ${ }^{4}$ and pulse wave velocity ${ }^{5}$, which reflect structural and functional properties of the arteries, respectively. In this study we aimed to investigate the parameters of aortic stiffness that were measured angiographically and the factors that affect these parameters in patients diagnosed as having MetS and whose coronary arteries were normal angiographically.

\section{Methods}

The study consisted of 30 consecutive patients with MetS who underwent coronary angiography for the evaluation of coronary artery disease (CAD). The working definition of the MetS proposed in the NCEP/ATP-III6 is based on the presence of three or more of the following five characteristics:

1. abdominal obesity (waist circumference:men>102 $\mathrm{cm}$, women $>88 \mathrm{~cm}$ ),

2. high blood pressure (BP) $(\geq 130 / 85 \mathrm{mmHg})$ or patient receiving antihipertensive treatment

3. high fasting glucose $(\geq 110 \mathrm{mg} / \mathrm{dl})$,

4. high triglycerides $(\geq 150 \mathrm{mg} / \mathrm{dl})$ and

5. reduced levels of high-density lipoprotein cholesterol (HDL) (men<40 mg/dl, women $<50$ mg/dl).

Patients with angiographic evidence of coronary artery disease were excluded from the study. All patients had angiographically normal coronary arteries by report. Angiographic findings were reviewed by three invasive cardiologs. Normal coronary angiogram was defined as absence of any visible angiographic sign of atherosclerosis and thrombosis. Patients with acute coronary syndro- mes, previously documented CAD, arrhythmia, suspected myocarditis or pericarditis, malignant disease, active inflammatory disease or advanced renal disease were also excluded. Diabetic patients were excluded from this study to avoid the contribution of diabetes as a potential confounder. The control group consisted of 20 subjects who had none of the 5 criteria of MetS described above and no history of obesity, dyslipidemia, hypertension and DM. They have never been diagnosed with DM, impaired glucose tolerance or any other systemic diseases The study was approved by hospital Ethics Committee and patients gave their written informed consent.

Anthropometric (height, weight and blood pressures), clinical and laboratory analysis were performed. Venous blood was collected after a minimum of 12 hours of fasting. Fasting plasma glucose, serum triglycerides (TG), serum total cholesterol (TC), high-density lipoprotein (HDL), low-density lipoprotein (LDL) and C-reactive protein (CRP) were tested using an auto biochemistry instrument (Abbott Architect c 16000). Plasma fasting insulin level was tested by radioimmunoassay. Body mass index (BMI) was calculated as weight in kilograms kilograms divided by height squared in meters $(\mathrm{kg} / \mathrm{m} 2)$. Homeostasis model assessment of insulin resistance (HOMA-IR) was calculated as insulin reading $(\mu \mathrm{IU} / \mathrm{mL})$ multiplied by plasma glucose level ( $\mathrm{mmol} / \mathrm{L}$ ) and divided by 22.5 .7

\section{Angiographic measurements}

Hemodynamic measurements were made in catheterization laboratory during coronary catheterization in supine position. Aortic pressure was obtained from the ascending aorta using a fluid filled system (pig tail catheter). The systolic and diastolic pressure traces of aorta were drawn on a band with a velocity of $25 \mathrm{~mm} / \mathrm{sec}$. For evey patient a mean number of 6-9 traces were taken and analyzed for measurements. Aortic pulse pressure was estimated as aortic diastolic pressure minus systolic pressure. The diastolic and systolic diameters of ascending aorta were measured from the level of $3 \mathrm{~cm}$ above the aortic valve during ventriculography. Measurements were made by Siemens cardiac catheterization device (Axiom Artis BC biplane). For strain and distensibility me- 
asurements the following formulas were used :8 Aortic strain $(\%)=$ (Systolic aortic diameter - diastolic aortic diameter) $\times 100 /$ diastolic aortic diameter.

Aortic distensibility (cm2.dyn-1.10-3) $=(2 \times$ Aortic strain) / pulse pressure.

\section{Statistical analysis}

SPSS for Windows 13.0 was used for statistical analyses. We expressed variables as mean values with standard deviations. The cathegoric variables were compared using Fisher's exact chi-square test. The variables were compared between two groups using independent samples $t$ test and Mann Whitney $U$ Test. The correlation between variables was evaluated by Pearson correlation coefficient. Multi variable regression analyses were made to determine variables associated to aortic distensibility. We accepted $p<0.05$ value as statistically significant for our analyses in our study.

\section{Results}

A summary of anthropometric, biochemical, and clinical char $\neg$ acteristics according to the presence of the MetS is shown in Table 1. MetS group showed higher levels of $\mathrm{BMI}$, waist circumference, insuline resistance, HOMA$I R$, serum $T G$ and fasting glucose, as well as lowered HDL levels than did control subjects. In the group with MetS pulse pressure, systolic pressures and diastolic pressure were found to be higher compared to control group. When two groups were compared according to pulse pressure, aortic strain and aortic distensibility; pulse pressure was significantly higher, aortic distensibility was lower in MetS group and aortic strain was similar in two groups (Table 2). In addition although insulin resistance was significantly higher in MetS group (MetS: \%30, control: \%5, $p=0,037$ ) and HOMA-IR (MetS: 2,96 \pm 2 , control: $1,5 \pm 0,8, p=0,007)$ levels were significantly higher in MetS group, there was not any significant relation between aortic distensibility and HOMA-IR or insülin resistance $(p=0,61)$. More over aortic distensibility was found to be related to waist circumference $(r=-0,589$, $p<0,001)$, fasting plasma glucose $(r=-0,721, p<0,001)$, pulse pressure $(r=-0,676, p<0,001)$, systolic blood pressure $(r-0,729, p<0,001)$ and diastolic blood pressure $(r=$
$-0,425, p=0,002)$ in the whole study population.

\begin{tabular}{|c|c|c|c|}
\hline Age (years) & $\begin{array}{c}\text { MetS pa- } \\
\text { tients } \\
n=30\end{array}$ & $\begin{array}{c}\text { Control } \\
n=20\end{array}$ & $\begin{array}{c}\mathrm{p} \\
\text { value }\end{array}$ \\
\hline Age (years) & $52 \pm 7,8$ & $54 \pm 9,3$ & NS \\
\hline Gender (male/female) & $4 / 26$ & $8 / 12$ & a $p=0,044$ \\
\hline BMI $\left(\mathrm{kg} / \mathrm{m}^{2}\right)$ & $31,66 \pm 4,6$ & $27,97 \pm 4,53$ & a $p=0,003$ \\
\hline $\mathrm{TC}(\mathrm{mg} / \mathrm{dl})$ & $222,4 \pm 45,2$ & $205,6 \pm 57,1$ & NS \\
\hline $\mathrm{HDL}-\mathrm{C}(\mathrm{mg} / \mathrm{dl})$ & $43,1 \pm 7,5$ & $52,4 \pm 12,2$ & a $p<0,001$ \\
\hline LDL-C (mg/dl) & $\begin{array}{c}135,86 \pm \\
37,57\end{array}$ & $134,3 \pm 49,9$ & NS \\
\hline $\mathrm{TG}(\mathrm{mg} / \mathrm{dl})$ & $216,7 \pm 94,6$ & $107,8 \pm 27,2$ & a $p<0,001$ \\
\hline $\begin{array}{l}\text { Glucose (fasting) } \\
\text { (mg/dl) }\end{array}$ & $104,1 \pm 18$ & $83,5 \pm 4,9$ & a $p<0,001$ \\
\hline $\begin{array}{l}\text { Waist circumference } \\
\text { (cm) }\end{array}$ & $102 \pm, 11,7$ & $92,7 \pm 6$ & a $p=0,005$ \\
\hline Üric aside (mg/dl) & $4,94 \pm 1,6$ & $4,2 \pm 1,9$ & NS \\
\hline İnsülin resistance (\%) & 30 & 5 & a $p=0,037$ \\
\hline Smoking (\%) & 36,7 & 30 & NS \\
\hline HOMA-IR & $2,96 \pm 2$ & $1,5 \pm 0,8$ & a $p=0,007$ \\
\hline
\end{tabular}

Table 2. Angiographic parameters of the enrolled patients.

\begin{tabular}{|l|c|c|c|}
\hline & $\begin{array}{c}\text { MetS } \\
\text { patients } \\
\mathrm{n}=30\end{array}$ & $\begin{array}{c}\text { Control } \\
\mathrm{n}=20\end{array}$ & $\begin{array}{c}\mathrm{p} \\
\text { value }\end{array}$ \\
\hline $\begin{array}{l}\text { Pulse pressure } \\
\text { (mmHg) }\end{array}$ & $56,3 \pm 8,8$ & $33,5 \pm 4,8$ & $\mathrm{p}<0,001$ \\
\hline $\begin{array}{l}\text { Aortic systolic } \\
\text { diameter (cm) }\end{array}$ & $3,34 \pm 0,39$ & $3,04 \pm 0,29$ & $\mathrm{p}=0,007$ \\
\hline $\begin{array}{l}\text { Aortic diastolic } \\
\text { diameter (cm) }\end{array}$ & $3,15 \pm 0,38$ & $2,8 \pm 0,29$ & $\mathrm{p}=0,01$ \\
\hline $\begin{array}{l}\text { Systolic blood } \\
\text { pressure (SBP) } \\
\text { (mmHg) }\end{array}$ & $136,3 \pm 14$ & $109,5 \pm 6,8$ & $\mathrm{p}<0,001$ \\
\hline $\begin{array}{l}\text { Diastolic blood } \\
\text { pressure(DBP) } \\
\text { (mmHg) }\end{array}$ & $80 \pm 10,5$ & $70 \pm 5,1$ & $\mathrm{p}=0,04$ \\
\hline Aortic strain (\%) & $6,04 \pm 1,4$ & $5,8 \pm 1,7$ & $\mathrm{p}=0,181$ \\
\hline $\begin{array}{l}\text { Aortic distensibilite } \\
\text { (cm2.dyn-1.10-3) }\end{array}$ & $1,64 \pm 0,5$ & $2,58 \pm 0,58$ & $\mathrm{p}<0,001$ \\
\hline
\end{tabular}


When multi-variable regresyon analyses were made and aortic distensibility was selected as independent variable, systolic blood pressure $(\square=-0,17 p=0,004)$ and fasting plasma glucose $(\square=-0,16 p=0,03)$ were independently related to aortic distensibility. There was not relation between aortic distensibility and other MetS parameters or lipid parameters.

\section{Discussion}

MetS is the combination of cardiovascular risk factors and as a whole syndrome or each parameter of which by itself causes increased risk for cardiovascular adverse events. ${ }^{9}$ There is linear relation between mortality and the number of MetS. ${ }^{10}$ In the recent studies the elasticity loss large arteries was found to be related to advers cardiovascular events. ${ }^{11}$ Aortic stiffness is an independent predictor of cardiovascular or all cause mortality apart from age, diabetes mellitus or previous cardiovascular events. ${ }^{12}$ The increase of arterial stiffness in patients with MetS has been reported in many studies. ${ }^{13-15}$ The increase in arterial stiffness is an important predictor of vascular aging ${ }^{16,17}$ and this occurs in earlier in patients with MetS. ${ }^{18,19}$

Many methods have been defined for evaluating aortic stiffness. These techniques varies from simple methods such as measurement of brachial pulse pressure by sphingomanometry to detailed and complex device required methods like pulse wave velocity, aortic impedance and aortic elasticity coefficient. The measurement of changes in aortic diameter invasively using ultrasonographic catheters gives information about aortic distensibility. ${ }^{20}$ As a non invasive method echocardiography can be used to investigate the pulsatile changes in aortic diameter and aortic distensibility. ${ }^{21}$ In this study we estimated the aortic diameter variability by an invasive method, angiography.

The measurement of blood pressure from brachial artery by sphingomanometry is not as sensitive as invasive catheter measurement. ${ }^{22,23}$ Physiologically, pulse pressure increases from central to periphere, for this reason pulse pressure obtained invasively reflects arterial elasticity more correctly. In our study pulse pressure was found to be higher in MetS group compared to control group, but we found no relation between pulse pressure and aortic distensibility.

Insulin resistance, which has an important role in physiopathology of MetS, has been shown to be related to arterial stiffness indicators of patients with or without DM. This relation is independent from age and other cardiovascular risk factors. ${ }^{24}$ Surprisingly while in healhty subjects insulin reduces augmentation index, an indicator of stiffness of large arteries, in insulin resistant states higher levels of insulin is required fort this effect of insulin. ${ }^{25}$ In our study we showed that age, systolic and diastolic blood pressure, fasting plasma glucose was independently related to aortic distensibility, but we could not find any relation between MetS and insulin resistance, which is estimated by HOMA-IR index and is found higher in MetS group. This conclusion is explained by small number of patients contained by study population. The most important restriction of our study is that we based normal coronary artery definement on angiographic findings. Due to lack of information obtained by coronary angiography compared to intravascular US, the intravascular US performing could be more appropriate in our study. Second important restriction is the small number patients in both groups. Another restriction is that we did not compare the stiffness of large arteries we obtained with another method such as pulse wave velocity, which is accepted as gold standard. The distensibility changes of central arteries are thought to more important predictors of cardiovascular events compared to peripheral changes. Studies carried out have suggested that DM and MetS effects peripheral arterial stiffness more than central arteries. ${ }^{26}$ This difference may be caused by patient groups involved and different methods used. When we think of higher morbidity and mortality in both conditions, it seems more likely that large arteries are affected earlier. Although we evaluated only stiffness of large arteries in our study, the higher peripheral pulse pressure of patients with MetS suggests that peripheral arteries are affected by the same process.

In conclusion, our findings suggest that aortic distensibility of patients with MetS and angiographically normal 
coronary arteries is increased and aortic pulse pressure is decreased compared to control group. So we can conclude that aortic stiffness is associated to the mechanism of increased cardiovascular events in patients with MetS. It is thoughtful to widen this subject by new

\section{References}

1. Reaven GM: Banting lecture 1988: Role of insulin resistance in human disease. Diabetes 1988;37(12):1595-1607.

2. Isomaa B, Almgren $P$, Tuomi $T$, Forsén $B$, Lahti $K$, Nissén $M$, et al.: Cardiovascular morbidity and mortality associated with the metabolic syndrome. Diabetes Care 2001;24(4):683-9.

3. Lorenzo C, Okoloise M, Williams K, Stern MP, Haffner SM, San Antonio Heart Study: The metabolic syndrome as predictor of type 2 diabetes: the San Antonio heart study. Diabetes Care 2003;26(11):3153-59

4. McNeill AM, Rosamond WD, Girman CJ, Heiss G, Golden SH, Duncan BB, et al: Prevalence of coronary heart disease and carotid arterial thickening in patients with the metabolic syndrome (The ARIC Study). Am J Cardiol 2004;94(10):1249-54.

5. Czernichow S, Bertrais S, Blacher J, Oppert JM, Galan P, Ducimetière $P$, et al. Metabolic syndrome in relation to structure and function of large arteries: a predominant effect of blood pressure. A report from the SU.VI.MAX. Vascular Study. Am J Hypertens 2005;18(9 Pt 1):1154-60

6. Expert Panel on Detection, Evaluation, And Treatment of High Blood Cholesterol In Adults (Adult Treatment Panel III). Expert Panel on Detection, Evaluation, and Treatment of High Blood Cholesterol in Adults. JAMA 2001;285(19): 2486-97.

7. Haffner SM, Miettinen H, Stern MP. The homeostasis model in

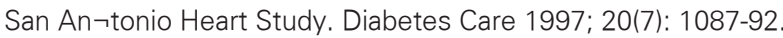

8. Lacombe F, Dart A, Dewar E, Jennings G, Cameron J, Laufer E. Arterial elastic properties in man: a comparison of echo-Doppler indices of aortic stiffness. Eur Heart J 1992;13(8):1040-5.

9. Girman CJ, Rhodes T, Mercuri M, Pyörälä K, Kjekshus J, Pedersen $\mathrm{TR}$, et al. The metabolic syndrome and risk of major coronary events in the Scandinavian Simvastatin Survival Study (4S) and the Air Force/ Texas Coronary Atherosclerosis Prevention Study. Am J Cardiol 2004; 93(2): 136- 41.

10. Ford ES. The metabolic syndrome and mortality from cardiovascular disease and all-causes: findings from the National Health and Nutrition Examination Survey II Mortality Study. Atherosclerosis 2004; 173(2):309-14.

11. Liao D, Arnett DK, Tyroler HA, Riley WA, Chambless LE, Szklo M, approaches and strategies to reduce aortic stiffness in patients with MetS in the future.

Conflict-of interest issues regarding the authorship or article: None declared

et al. Arterial stiffness and the development of hypertension. The ARIC study. Hypertension 1999;34(2): 201-6.

12. Laurent S, Boutouyrie P, Asmar R, Gautier I, Laloux B, Guize L, et al. Aortic stiffness is an independent predictor of all-cause and cardiovascular mortality in hypertensive patients. Hypertension 2001;37(5): 1236-41

13. Scuteri A, Najjar SS, Muller DC, Andres R, Hougaku H, Metter EJ, et al. Metabolic syndrome amplifies the age-associated increases in vascular thickness and stiffness. J Am Coll Cardiol 2004;43(8): 1388-95.

14. Safar ME, Thomas F, Blacher J, Nzietchueng R, Bureau JM, Pannier B, et al. Metabolic syndrome and age related progression of aortic stiffness. J Am Coll Cardiol 2006;47(1): 72-5.

15. Asman G, Sculte H, Seedorf U. The Prospective Cardiovascular Munster (PROCAM) Study: Prevalence of hiperlipidemia in persons with hypertension and/ or diabetes mellitus and the relationship to coronary heart disease. Am Heart J 1998; 11616 Pt 2): 1713- 24

16. Stehouwer $C D$, Henry RM, Ferreira I. Arterial stiffness in diabetes and the metabolic syndrome: a pathway to cardiovascular disease. Diabetologia 2008; 51(4): 527-39.

17. Li S, Chen W, Srinivasan SR. et al. Influence of metabolic syndrome on arterial stiffness and its age related change in young adults: the Bogalusa Heart Study. Atherosclerosis 2005;180(2):349-54.

18. Schillaci G, Pirro M, Vaudo G, Mannarino MR, Savarese G, Pucci $\mathrm{G}$, et al. Metabolic syndrome is associated with aortic stiffness in untreated essential hypertension. Hypertension 2005;45(6): 1078-82.

19. Ferreira I, Henry RM, Twisk J W. van Mechelen W, Kemper HC, Stehouwer CD, et al. The metabolic syndrome, cardiopulmonary fitness, and subcutaneous trunk fat as independent determinants of arterial stiffness: the Amsterdam Growth and Health Longitudinal Study. Arch Intern Med 2005;165(8):875-82.

20. Stefanadis C, Dernellis J, Vlachopoulos C, Tsioufis C, Tsiamis E, Toutouzas K, et al. Aortic function in arterial hypertension determined by pressure-diameter relation: effects of diltiazem. Circulation 1997;96(6):1853-8. 
21. Lacombe F, Dart A, Dewar E, Jennings G, Cameron J, Laufer E. Arterial elastic properties in man: a comparison of echo-Doppler indices of aortic stiffness. Eur Heart J 1992;13(8):1040-5.

22. Wolf AM, Colditz GA. Current estimates of the economic cost of obesity in the United States. Obes. Res. 1998; 6(2): 97-106

23. Vardan S, Smulyan H, Mookherjee S, Hill NE, Gens J, Willsey GA. Importance of intraarterial blood pressure measurement in the evaluation of a new antihypertensive agent and the need to define hypertension also by this method. Ann $\mathrm{J}$ Hypertens 1990;3(11): 901-2.

24. Sutton Tyrrell K, Newman A, Simonsick EM, Havlik R, Pahor M, Lakatta E, et al. Aortic stiffness is associated with visceral adiposity in older adults enrolled in the study of health, aging, and body composition. Hypertension 2001; 38(3): 429 -33

25. Westerbacka J, Vehkavaara S, Bergholm R, Wilkinson I, Cockcroft $\mathrm{J}$, Yki-Jarvinen $\mathrm{H}$. Marked resistance of the ability of insulin to decrease arterial stiffness characterizes human obesity. Diabetes 1999;48(4):821-7.

26. Protogerou AD, Blacher J, Aslangul E, Le Jeunne C, Lekakis J, Mavrikakis M, et al. Gender influence on metabolic syndrome's effects on arterial stiffness and pressure wave reflections in treated hypertensive subjects. Atherosclerosis 2007;193(1):1518. 